\title{
Carbon-Hydrogen bond activation
}

\section{Hall}

\author{
Address: Texas A\&M University, College Station, Texas 77843-3255, USA \\ from 4th German Conference on Chemoinformatics \\ Goslar, Germany. 9-II November 2008 \\ Published: 5 June 2009 \\ Chemistry Central Journal 2009, 3(Suppl I):P46 doi:I0.II86/1752-I53X-3-SI-P46
}

This abstract is available from: http://www.journal.chemistrycentral.com/content/3/SI/P46

(c) 2009 Hall; licensee BioMed Central Ltd.

In early experimental studies of transition-metal activation of methane two alternative mechanisms were invoked: an exchange reaction via a sigma-bond metathesis route and the oxidative addition of methane to form a stable metal methyl hydride. Computational chemistry has provided considerable insight into details of the mechanisms operating in these bond activation reactions. For the low-temperature activation of alkanes by $\left[\mathrm{Cp}{ }^{*} \operatorname{Ir}(\mathrm{PMe} 3)(\mathrm{CH} 3)\right]^{+}$density functional calculations predict an oxidative-addition pathway with a stable $\operatorname{Ir}(\mathrm{V})$ intermediate. Both of these mechanisms appear to be accessible for $\mathrm{C}-\mathrm{H}$ activation by the reactive carbene intermediate $\mathrm{Cp}^{*} \mathrm{~W}(=\mathrm{CRH}) \mathrm{L}, \mathrm{L}=\mathrm{NO}, \mathrm{CO}$. Recently, in cases where the optimized transition states appear to resemble geometrically an oxidative-addition intermediate, various research groups have suggested alternative $\mathrm{C}-\mathrm{H}$ activation mechanisms. A Bader analysis of these transition states is capable of resolving these alternatives and classifying them into a range of mechanisms. Recently, time resolved infrared spectroscopy and density functional calculations have revealed new details about the intermediates and transition states involved in the oxidative-addition reaction of alkanes by photochemically generated $\mathrm{TpRh}(\mathrm{CO})$ and $\mathrm{CpRh}(\mathrm{CO})$. 